\title{
The effect of sleep deprivation on pain
}

\author{
Bernd Kundermann Dipl-Psych¹, Jürgen-Christian Krieg MD¹, Wolfgang Schreiber MD ${ }^{1}$, Stefan Lautenbacher PhD²
}

\author{
B Kundermann, J-C Krieg, W Schreiber, S Lautenbacher. The \\ effect of sleep deprivation on pain. Pain Res Manage \\ 2004;9(1):25-32.
}

Chronic pain syndromes are associated with alterations in sleep continuity and sleep architecture. One perspective of this relationship, which has not received much attention to date, is that disturbances of sleep affect pain. To fathom this direction of cause, experimental human and animal studies on the effects of sleep deprivation on pain processing were reviewed. According to the majority of the studies, sleep deprivation produces hyperalgesic changes. Furthermore, sleep deprivation can counteract analgesic effects of pharmacological treatments involving opioidergic and serotoninergic mechanisms of action. The heterogeneity of the human data and the exclusive interest in rapid eye movement sleep deprivation in animals so far do not allow us to draw firm conclusions as to whether the hyperalgesic effects are due to the deprivation of specific sleep stages or whether they result from a generalized disruption of sleep continuity. The significance of opioidergic and serotoninergic processes as mediating mechanisms of the hyperalgesic changes produced by sleep deprivation are discussed.

\section{L'effet du manque de sommeil sur la douleur}

Les syndromes de douleur chronique s'associent à des altérations de la continuité et de l'architecture du sommeil. L'une des perspectives de ce lien, qui n'a pas reçu beaucoup d'attention jusqu'à présent, c'est que les troubles du sommeil influent sur la douleur. Pour sonder cette orientation de la cause, on a analysé des études expérimentales menées sur des humains et sur des animaux afin d'établir les effets du manque de sommeil sur le mécanisme de la douleur. D'après la plupart des études, le manque de sommeil produit des modifications hyperalgésiques. De plus, il peut contrer les effets analgésiques des traitements pharmacologiques mettant an cause des modes d'action opioïdénergiques et sérotinergiques. L'hétérogénéité des données humaines et l'intérêt exclusif pour le manque de sommeil paradoxal chez les animaux jusqu'à présent nous empêchent d'établir avec certitude si les effets hyperalgésiques sont imputables au manque de phases précises du sommeil ou à un dérèglement généralisé de la continuité du sommeil. On se penche sur l'importance des processus opioïdergiques et sérotinergiques à titre de mécanismes médiateurs des modifications hyperalgésiques produites par le manque de sommeil.

Key Words: Opioids; Pain; Serotonin; Sleep deprivation

$\mathrm{P}$ atients with chronic pain syndromes often suffer from sleep disturbances (1). However, it is difficult to determine the direction of cause between pain and sleep disturbance. The usual perspective favours an arousal-augmenting function of pain, which prevents the initiation or the continuation of sleep. Alternatively, it is believed that the modulation of pain and sleep-wake regulation share common neurobiological systems, in particular the central serotoninergic one (2). Consequently, the association of pain and disturbed sleep might be a secondary phenomenon due to a common neurobiological dysfunction. Finally, a rather unusual perspective is that poor sleep can interfere with pain processing. With this latter direction of relation in mind, we have addressed the following issues by reviewing the literature with a clear focus on experimental studies. The following perspectives may help to integrate the reviewed findings.

1. The relationship between sleep disturbances and pain as suggested by correlational data. The majority of studies on the relationship between sleep and pain were not based on an experimental design, but relied on correlations only. In this section, a brief summary of the clinical investigations is given, including their first clues concerning the influence of disturbed sleep on pain, and their limitation in deriving causal relations.

2. Sleep deprivation as a methodological approach to mimic disturbed sleep and derive experimental evidence for algesic effects. A comprehensive review of animal and human studies, which used sleep deprivation as an independent variable and examined its influence on pain processing, is provided.

3. Assumptions on the algesic mechanisms of sleep deprivation. Results from animals studies suggest various neurochemical changes during and after sleep deprivation, which seemed to be involved in the modulation of pain. With a focus on the serotoninergic system, sleep deprivation affects 5-hydroxytryptamine (5-HT) turnover (3), the firing rate of serotoninergic neurons in the dorsal nucleus raphé (4) and 5-HT receptor functions (5). Given the well-known pain inhibitory effects of 5 -HT, these changes may be tentatively integrated into a serotoninergic model of hyperalgesic action of sleep deprivation.

${ }^{1}$ Department of Psychiatry and Psychotherapy, Philipps University Marburg, Marburg, Germany; ${ }^{2}$ Physiological Psychology, University of Bamberg, Bamberg, Germany

Correspondence: B Kundermann, Department of Psychiatry and Psychotherapy, Philipps University Marburg, Rudolf-Bultmann-Str 8, D-35033 Marburg, Germany. Telephone +49-6421-2865187, fax +49-6421-2865431, e-mail kunderma@med.uni-marburg.de 


\section{THE RELATIONSHIP BETWEEN SLEEP AND PAIN AS SUGGESTED BY CORRELATIONAL DATA}

The overnight augmentation of muscular pain in fibromyalgia patients led to the assumption of a pathogenic role of disturbed sleep in pain conditions. Moldofsky et al (6) were among the first to investigate both sleep physiology and pain in fibromyalgia patients. They observed an increased ratio of alpha waves during nonrapid eye movement (NREM) sleep, the so-called "alpha-delta sleep". The authors suggested that an increased arousal during slow wave sleep interferes with the restorative function of sleep. Interestingly, the pressure pain thresholds markedly decreased from evening to morning in parallel.

Subsequent polysomnographic studies, in which nocturnal sleep of healthy subjects was assessed for comparison, failed to confirm a fibromyalgia specificity of the alpha-delta sleep. Horne and Shackell (7) found no significant differences in the ratio of alpha activity in NREM sleep between fibromyalgia patients and healthy control subjects. Furthermore, an increased ratio of alpha waves during NREM sleep was observed in other conditions of chronic pain (eg, in rheumatoid arthritis [8], and in conditions with primary insomnia [9]). However, these findings showing a lack of specificity of alpha-delta sleep for fibromyalgia do not rule out the assumed contribution of disturbed sleep to the development of chronic pain. This assumption was strengthened by a recent study by Argargün et al (10) of fibromyalgia patients. The subjective quality of sleep as assessed by the Pittsburgh Sleep Quality Index was inversely related to pressure pain sensitivity in these patients.

Given that disturbed sleep may contribute to chronic pain, the question arises whether the effect is direct or mediated by other factors. Jennum et al (11) showed that in comparison to healthy control subjects, fibromyalgia patients exhibit more arousal episodes during night sleep. However, this group difference in sleep architecture was strongly related to the occurrence of respiratory disorders in patients with fibromyalgia. Thus, the apparent causation may reflect third-party factors. Depression also needs to be considered as a mediating factor because of its association with sleep disorders and chronic pain (12).

Finally, there is also evidence that disturbed sleep augments acute pain. Raymond et al (13) investigated inpatients with burn injuries. The subjective quality of night sleep was a significant predictor for pain intensity on the following day. In contrast, the pain intensity of the day before did not predict the sleep quality of the following night.

The correlational data reported here suggest that sleep disturbances caused by pain facilitate subsequent pain. However, it is not clear whether a change in sleep architecture or a deprivation of certain sleep stages is the relevant etiological factor. The next section provides a systematic review of experimental data on the effects of sleep deprivation on pain to address this question.

\section{EXPERIMENTAL ANALYSIS OF THE EFFECT OF SLEEP DEPRIVATION ON PAIN}

This review of the literature is based on MEDLINE research for the years 1962 to October 2003 using the keywords "sleep", "sleep deprivation" and "sleep interruption", combined with "pain", for human and animal studies. An article was included if sleep deprivation in its total, selective or partial form was used as an independent variable, and any subjective or behavioural measure of pain was used as a dependent variable. Furthermore, only studies that met minimal methodological requests (with respect to sample size and description, control of sleep deprivation, quality of pain measurement and suitability of statistics) were reviewed.

\section{HUMAN DATA}

A total of seven studies met the inclusion criteria (Table 1). The guiding study in this field is the one by Moldofsky et al (6); clinical aspects of this study were already considered in the preceding section. The authors proposed that an NREM sleep disturbance is involved in the pathogenesis of fibromyalgia, and that NREM sleep interruption causes myalgic pain. Six healthy men underwent a selective (stage 4) sleep deprivation period for three nights. Sleep deprivation was preceded by an adaptation night and followed by a recovery night. During each experimental phase, pressure pain sensitivity was measured at the respective tender points for the diagnosis of fibromyalgia. Muscular pain was assessed using a rating scale. During the stage 4 sleep deprivation period, both pressure pain sensitivity and muscular pain increased. The changes were accompanied by an increased arousal seen on the sleep electroencephalogram (EEG) but not by prolonged periods of being awake. The validity of this study was hampered by the fact that a control group was missing. Thus, the changes observed might have been due to unfamiliar sleeping conditions in a laboratory, or might have resulted from any kind of sleep disruption, not necessarily from deprivation of sleep stage 4.

Some of these objections were addressed in a second study by Moldofsky and Scarisbrick (14) by adding the results of a second group to the data of Moldofsky et al (6). Seven healthy individuals were deprived selectively from rapid eye movement (REM) sleep in the same experimental setting. REM sleep deprivation did not lower the pressure pain thresholds, and muscular pain increased only to a small degree. Thus, the marked changes observed after stage 4 sleep deprivation were not replicated by REM sleep deprivation.

In contrast to those studies, Drewes et al (15) analyzed the effects of total sleep deprivation on pain detection (for pressure and heat) and tolerance thresholds (for pressure) in 10 healthy individuals. The repeated measurements at short intervals of $2 \mathrm{~h}$ (starting at 23:00 and ending at 07:00), with an additional assessment the next day (at 23:00), indicated no changes in pain detection and tolerance thresholds. The study by Older et al (16) was one of the few controlled ones comparing three days of noise-induced disruption of slow wave sleep in 13 subjects with three days of normal night sleep in six subjects. Furthermore, the potential role of hormones as a mediating factor between sleep and pain was tested by assessing insulin-like growth factor (IGF-1). The idea of an involvement of IGF-1 in the relation between disturbed sleep and pain was derived from observations on fibromyalgia patients, who tend to have low IGF-1 levels. The EEG showed more arousal during slow wave sleep deprivation and an increased portion of REM sleep. However, pressure pain thresholds and IGF-1 serum levels did not change. In contrast, somatic complaints increased after the third night of sleep deprivation. 
TABLE 1

Human experiments on the effects of sleep deprivation on pain

\begin{tabular}{|c|c|c|c|c|c|}
\hline Author (reference) & Subjects & Treatment & Design & Pain-related measurements & Main results \\
\hline $\begin{array}{l}\text { Moldofsky et al, } \\
1975 \text { (6) }\end{array}$ & $\begin{array}{l}\text { Healthy } \\
\text { males, } \\
n=6\end{array}$ & $\begin{array}{l}\text { SW-SD for } \\
3 \text { consecutive } \\
\text { nights }\end{array}$ & $\begin{array}{l}\text { Repeated measures over } \\
7 \text { days with the conditions } \\
\text { - baseline } \\
\text { - treatment } \\
\text { - recovery }\end{array}$ & $\begin{array}{l}\text { Pain thresholds: } \\
\text { - mechanical ( } 26 \text { sites in the } \\
\text { musculoskeletal system, which are } \\
\text { vulnerable in fibromyalgia patients) } \\
\text { Subjective ratings of body complaints }\end{array}$ & $\begin{array}{l}\text { Decreased mechanical } \\
\text { pain thresholds after SW-SD } \\
\text { More musculosketal } \\
\text { symptoms after SW-SD }\end{array}$ \\
\hline $\begin{array}{l}\text { Moldofsky and } \\
\text { Scarisbrick, } \\
1976(14)\end{array}$ & $\begin{array}{l}\text { Healthy } \\
\text { subjects, } \\
n=13 \\
\text { (12 males, } \\
1 \text { female) }\end{array}$ & $\begin{array}{l}\text { SW-SD vs } \\
\text { REM-SD for } \\
3 \text { consecutive } \\
\text { nights }\end{array}$ & $\begin{array}{l}\text { Comparison of two } \\
\text { independent groups (SW- vs } \\
\text { REM-SD) including repeated } \\
\text { measures over } 7 \text { days with } \\
\text { the conditions: } \\
\text { - baseline } \\
\text { - treatment } \\
\text { - recovery }\end{array}$ & $\begin{array}{l}\text { Pain thresholds: } \\
\text { - mechanical ( } 26 \text { sites in the } \\
\text { musculoskeletal system, which } \\
\text { are vulnerable in fibromyalgia } \\
\text { patients) } \\
\text { Subjective ratings of body } \\
\text { complaints }\end{array}$ & $\begin{array}{l}\text { Decreased mechanical } \\
\text { pain thresholds after SW-SD, } \\
\text { but no changes in mechanical } \\
\text { pain thresholds after REM-SD } \\
\text { SW-SD-group reported } \\
\text { after the SD-nights more } \\
\text { musculosketal symptoms } \\
\text { compared with REM-SD group }\end{array}$ \\
\hline $\begin{array}{l}\text { Drewes et al, } \\
1997(15)\end{array}$ & $\begin{array}{l}\text { Healthy } \\
\text { subjects, } \\
n=10\end{array}$ & $\begin{array}{l}\text { Total SD for } \\
1 \text { night }\end{array}$ & $\begin{array}{l}\text { Repeated measures during } \\
\text { the night and following day }\end{array}$ & $\begin{array}{l}\text { Pain thresholds: } \\
\text { - mechanical (pain detection } \\
\text { and pain tolerance thresholds) } \\
\text { - thermal (pain detection thresholds) }\end{array}$ & $\begin{array}{l}\text { No changes in pain } \\
\text { detection and tolerance } \\
\text { thresholds over the time }\end{array}$ \\
\hline $\begin{array}{l}\text { Older et al, } \\
1998(16)\end{array}$ & $\begin{array}{l}\text { Healthy } \\
\text { subjects, } \\
n=19\end{array}$ & $\begin{array}{l}\text { SW-SD for } \\
3 \text { consecutive } \\
\text { nights }\end{array}$ & $\begin{array}{l}\text { Controlled comparison of } \\
\text { two independent groups } \\
\text { (SW-SD vs. untreated } \\
\text { controls) including repeated } \\
\text { measures over } 7 \text { days with } \\
\text { the conditions: } \\
\text { - baseline } \\
\text { - treatment } \\
\text { - recovery }\end{array}$ & $\begin{array}{l}\text { Pain thresholds: } \\
\text { - mechanical } \\
\text { Subjective rating of body } \\
\text { complaints (VAS) } \\
\text { Neuroendocrine assessment: } \\
\text { - IGF-1 }\end{array}$ & $\begin{array}{l}\text { No differences in pain thresholds } \\
\text { within or between groups } \\
\text { More body complaints } \\
\text { after third SW-SD Night } \\
\text { (compared with controls) } \\
\text { No changes of IGF-1 after SD }\end{array}$ \\
\hline $\begin{array}{l}\text { Lentz et al, } \\
1999(17)\end{array}$ & $\begin{array}{l}\text { Healthy } \\
\text { females, } \\
n=12\end{array}$ & $\begin{array}{l}\text { SW-SD for } \\
3 \text { consecutive } \\
\text { nights }\end{array}$ & $\begin{array}{l}\text { Repeated measures over } \\
5 \text { days with the conditions: } \\
\text { - baseline } \\
\text { - treatment }\end{array}$ & $\begin{array}{l}\text { Pain thresholds: } \\
\text { - mechanical: thresholds were } \\
\text { assessed on } 16 \text { specific sites, } \\
\text { which are vulnerable in } \\
\text { fibromyalgia, and on additional } \\
\text { two control sites } \\
\text { Skinfold tenderness } \\
\text { Skin reactive hyperemia } \\
\text { Subjective ratings of body } \\
\text { complaints }\end{array}$ & $\begin{array}{l}\text { Decreased tender point } \\
\text { pain thresholds after the second } \\
\text { and third SW-SD night, } \\
\text { compared with baseline } \\
\text { Pain thresholds on control sites } \\
\text { were decreased after third } \\
\text { SW-SD night } \\
\text { Higher skinfold tenderness } \\
\text { after the third SW-SD night } \\
\text { Increased vasodilatation } \\
\text { to mechanical stimulation } \\
\text { (inflammatory flare response) } \\
\text { after the third SW-SD night } \\
\text { More musculosketal discomfort } \\
\text { after the third SW-SD night }\end{array}$ \\
\hline $\begin{array}{l}\text { Arima et al, } \\
2001(18)\end{array}$ & $\begin{array}{l}\text { Healthy } \\
\text { males, } \\
n=10\end{array}$ & $\begin{array}{l}\text { SW-SD for } \\
3 \text { consecutive } \\
\text { nights }\end{array}$ & $\begin{array}{l}\text { Repeated measures over } \\
6 \text { days with the conditions: } \\
\text { - baseline } \\
\text { - treatment } \\
\text { - recovery }\end{array}$ & $\begin{array}{l}\text { Pain thresholds: } \\
\text { - mechanical (masseter muscle) } \\
\text { EMG (masseter muscle) } \\
\text { Maximum voluntary occlusal force } \\
\text { Subjective rating of body } \\
\text { complaints (VAS) }\end{array}$ & $\begin{array}{l}\text { No effects of SW-SD on } \\
\text { pain thresholds } \\
\text { No effects of SW-SD on } \\
\text { EMG activity, maximum } \\
\text { voluntary occlusal force and } \\
\text { VAS ratings }\end{array}$ \\
\hline $\begin{array}{l}\text { Onen et al, } \\
2001 \text { (19) }\end{array}$ & $\begin{array}{l}\text { Healthy } \\
\text { males, } \\
n=9\end{array}$ & $\begin{array}{l}\text { Total SD for } \\
1 \text { night, the } \\
\text { following } 2 \\
\text { nights } \\
\text { - REM-SD or } \\
\text { - SW-SD }\end{array}$ & $\begin{array}{l}\text { Controlled crossover study } \\
\text { with a counter-balanced } \\
\text { order of REM- and SW-SD } \\
\text { (two sequences). Repeated } \\
\text { measures over } 6 \text { days with } \\
\text { the conditions: } \\
\text { - baseline } \\
\text { - treatment } \\
\text { - recovery }\end{array}$ & $\begin{array}{l}\text { Pain thresholds: } \\
\text { - thermal (pain tolerance } \\
\text { thresholds) } \\
\text { - mechanical (pain tolerance } \\
\text { thresholds }\end{array}$ & $\begin{array}{l}\text { Mechanical pain tolerance } \\
\text { thresholds were decreased } \\
\text { after total SD } \\
\text { Recovery sleep after } \\
\text { SW-SD produced increase in } \\
\text { mechanical pain tolerance } \\
\text { thresholds }\end{array}$ \\
\hline
\end{tabular}

EMG Electromyography; IGF-1 Insulin-like growth factor 1; REM-SD Rapid eye movement sleep deprivation; VAS Visual analogue scale; SD Sleep deprivation; SW-SD Slow wave sleep deprivation 
The findings of Older et al (16) were in contrast to the results of Lentz et al (17), who also investigated the effects of "slow wave sleep disruption" over three nights. Although the study was uncontrolled, the comprehensive assessment of pain highlights this study in comparison with others. At the tender points designated for the diagnosis of fibromyalgia, the pressure pain thresholds decreased after two or three nights of slow wave sleep disruption. The same response also occurred the control points after the third night. At this time, muscle complaints also became more frequent. Interestingly, the flare response gained strength during the course of slow wave sleep disruption, suggesting an activation of mechanisms involved in neurogenic inflammation.

The studies reported so far were partly designed to look for a relationship between sleep deprivation or disruption and the incidence of fibromyalgia-like pain, which is pain at various sites of the body. In contrast, an interest in the regional pain of temporomandibular disorder (TMD) inspired the study of Arima et al (18), conducted in 10 healthy men. The question was whether the pattern of sleep disruption observed in TMD patients, which is characterized by an increased amount of EEG desynchronization during night sleep, can be experimentally modelled in healthy individuals with the consequence of occurrence of TMD-like symptoms. A variety of tests for TMD-like symptomatology (eg, pressure pain threshold above the temporomandibular joint, occlusal force, electromyography of the masseter muscle, and visual analog scale ratings for pain and other somatic complaints) revealed no changes due to slow wave sleep disruption (disruption of NREM sleep stages 3 and 4 by use of a computer controlled sound stimulation). However, the validity of the findings is uncertain because no substantial reduction of the portion of slow wave sleep could be obtained during the second and third night of sleep deprivation. Furthermore, for the first nights, no compensatory increase of NREM sleep stages 1 and 2 was reported. It is unclear whether these findings indicate problems in the experimental procedures or in the statistics applied.

The best study, using current standards of methodology in this field, is the one by Onen et al (19). Sleep deprivation was accomplished in its total form, as "slow wave" and as REM sleep deprivation. The authors made use of a crossover design, in which nine healthy men ran through a night of total sleep deprivation for $40 \mathrm{~h}$, and then through two consecutive nights with either slow wave sleep or REM sleep interruption, ending with a recovery night in any case. Pain tolerance thresholds were assessed in the evening and in the morning. Total sleep deprivation decreased pressure pain tolerance thresholds compared with a baseline period, a finding that was not obtained for the heat pain tolerance thresholds. Both REM and slow wave sleep interruption tended to decrease pressure pain tolerance thresholds. Only recovery sleep after slow wave sleep interruption produced an increase in pressure pain tolerance thresholds, but not after REM sleep interruption. A compensatory larger portion of slow wave sleep stages 3 and 4 during the recovery night paralleled the increase in pressure pain tolerance thresholds.

\section{SUMMARY OF EXPERIMENTAL INVESTIGATIONS OF HUMANS}

There are only a few human studies available on the effects of sleep deprivation on pain, and the findings are not always consistent (Table 1). Nevertheless, the results tend to indicate that sleep deprivation does produce hyperalgesic changes in healthy subjects. Thereby, the term "hyperalgesic change" is not used to describe a pathophysiological state, but the direction of change in pain sensitivity. The deprivation or the disruption of slow wave sleep especially has appeared to exert this effect, whereas results on the effects of selective REM sleep deprivation remain unclear. The findings of Onen et al (19) suggest that slow wave sleep deprivation makes individuals more sensitive to noxious stimuli, and that recovery from this type of deprivation has the opposite effect. Interestingly, the hyperalgesic action of slow wave sleep deprivation was mainly observed when tested by pressure pain stimulation. Pressure pain stimulation targets both superficial and deep tissue nociception, whereas heat pain stimulation targets primarily superficial tissue nociception. Accordingly, pressure pain stimulation appears to reflect muscle and skin nociception, whereas heat pain stimulation allows only the assessment of skin nociception (20). Muscle nociception is likely to be influenced to a much stronger degree by the descending pain inhibitory control system than skin nociception (21). It is possible that slow wave sleep disruption affects this descending pain inhibitory control system and, thereby preferentially, pressure pain sensitivity. Such an effect is very likely a systemic, not a regional, one. The findings of Lentz et al (17) and Onen et al (19) corroborate the idea of a systemic change in pain sensitivity because similar results were obtained when testing multiple sites.

It should be critically noted that individual factors (eg, age or sex of study subjects), which have not yet been controlled sufficiently, may interact with the effects of sleep deprivation on pain. Furthermore, sleep deprivation is known to produce additional effects like sleepiness, increased fatigue, negative mood or cognitive dysfunctions, which might cause or mimic a modulation of pain processing. Other somatosensory functions (ie, responses to innocuous stimuli) might be of special relevance in this context and have been neglected so far. Therefore, it is still questionable whether the observed effects are due to specific alteration of pain processing. Finally, because all human studies were designed for ethical reasons to examine short term (up to three nights) effects of sleep deprivation only, these findings permit only a limited generalization to chronic pain conditions with weeks, months or even years of disturbed sleep.

\section{ANIMAL DATA}

Hicks et al (22) conducted the first experiment on animals investigating the effects of sleep deprivation on nociception (Table 2). In a controlled study in Sprague-Dawley rats, the authors assessed the effects of REM sleep deprivation on nociceptive sensitivity (tail flick to electrical stimuli). REM sleep deprivation rendered the rats more sensitive to the electrical stimuli for a long period of time, up to $24 \mathrm{~h}$. The duration of the deprivation (1, 2 or 3 days) was of no influence. Subsequently, Hicks et al (23) showed that REM sleep deprivation for four days decreased nociceptive thresholds for as long as $96 \mathrm{~h}$ after termination of the sleep deprivation procedure.

Ukponmwan et al (24) examined the relationship between REM sleep and opioidergic activity. To test this, Wistar rats were selectively deprived from REM sleep and compared with "stressed" animals and untreated (control) animals. After a 
TABLE 2

Animal experiments on the effects of sleep deprivation on pain

\begin{tabular}{|c|c|c|c|c|c|}
\hline Author (reference) & Animals & Treatment & Design & Pain-related measurements & Main results \\
\hline $\begin{array}{l}\text { Hicks et al, } \\
1978 \text { (22) }\end{array}$ & $\begin{array}{l}\text { Sprague- } \\
\text { Dawley rat, } \\
\mathrm{n}=36\end{array}$ & $\begin{array}{l}\text { REM-SD of } \\
\text { different length: } \\
1,2 \text { and } 3 \\
\text { consecutive days }\end{array}$ & $\begin{array}{l}5 \text { groups with repeated measures. } \\
\text { After preliminary analysis: } \\
\text { Comparison of two independent } \\
\text { groups (REM-SD vs. } \\
\text { untreated controls) }\end{array}$ & $\begin{array}{l}\text { Nociceptive thresholds: } \\
\text { - electrical (tail electric } \\
\text { shock test) }\end{array}$ & $\begin{array}{l}\text { Decreased nociceptive } \\
\text { thresholds immediately, } \\
3 \mathrm{~h} \text { and } 24 \mathrm{~h} \text { after REM-SD } \\
\text { Effect of decreased nociceptive } \\
\text { thresholds was independent to the } \\
\text { length of REM-SD }\end{array}$ \\
\hline $\begin{array}{l}\text { Hicks et al, } \\
1979(23)\end{array}$ & $\begin{array}{l}\text { Sprague- } \\
\text { Dawley rat, } \\
n=30\end{array}$ & $\begin{array}{l}\text { REM-SD for } 4 \\
\text { consecutive days }\end{array}$ & $\begin{array}{l}3 \text { groups with repeated measures. } \\
\text { After preliminary analysis: } \\
\text { Comparison of two independent } \\
\text { groups (REM-SD vs untreated } \\
\text { controls) }\end{array}$ & $\begin{array}{l}\text { Nociceptive thresholds: } \\
\text { - electrical (tail electric } \\
\text { shock test) }\end{array}$ & $\begin{array}{l}\text { Decreased nociceptive } \\
\text { thresholds immediately, } 24 \mathrm{~h} \text { and } \\
96 \mathrm{~h} \text { after REM-SD }\end{array}$ \\
\hline $\begin{array}{l}\text { Ukponmwan et al, } \\
1984(24)\end{array}$ & $\begin{array}{l}\text { Wistar rat, } \\
\mathrm{n}=210\end{array}$ & $\begin{array}{l}\text { REM-SD for } 4 \\
\text { consecutive days }\end{array}$ & $\begin{array}{l}3 \text { groups (REM-SD vs stress vs } \\
\text { controls) under the following } \\
\text { conditions: } \\
\text { (a) cold water-swim analgesia or } \\
\text { (b) phosphoramidon or } \\
\text { (c) morphine }\end{array}$ & $\begin{array}{l}\text { Nociceptive thresholds: } \\
\text { - mechanical (paw } \\
\text { pressure test) }\end{array}$ & $\begin{array}{l}\text { Conditions a, b und c produced } \\
\text { antinociceptive effects in stressed } \\
\text { and untreated (control-) rats } \\
\text { No antinociceptive effect of } \\
\text { conditions a, b and c in } \\
\text { sleep-deprived animals }\end{array}$ \\
\hline $\begin{array}{l}\text { Ukponmwan et al, } \\
1986(25)\end{array}$ & $\begin{array}{l}\text { Wistar rat, } \\
\mathrm{n} \geq 171\end{array}$ & $\begin{array}{l}\text { REM-SD for } 4 \\
\text { consecutive days }\end{array}$ & $\begin{array}{l}2 \text { groups (REM-SD vs controls) } \\
\text { under different pharmacological } \\
\text { conditions: } \\
\text { (a) deprenyl } \\
\text { (b) beta-phenylethylamine } \\
\text { (c) phosphoramidon } \\
\text { (d) deprenyl + phosphoramidon } \\
\text { (e) beta-phenylethylamine + } \\
\text { phosphoramidon } \\
\text { (f) deprenyl + beta-phenylethylamine } \\
\text { + phosphoramidon }\end{array}$ & $\begin{array}{l}\text { Nociceptive thresholds: } \\
\text { - mechanical (paw } \\
\text { pressure test) }\end{array}$ & $\begin{array}{l}\text { REM-SD decreased basal nociceptive } \\
\text { thresholds (without pharmacological } \\
\text { intervention) compared with } \\
\text { untreated (control) rats } \\
\text { Conditions } \mathrm{c}, \mathrm{d} \text {, e and f produced } \\
\text { increased nociceptive thresholds in } \\
\text { the control group compared with the } \\
\text { sleep deprived group } \\
\text { No differences in nociceptive } \\
\text { thresholds between REM-SD and } \\
\text { control group under conditions a and b }\end{array}$ \\
\hline $\begin{array}{l}\text { Asakura et al, } \\
1992(26)\end{array}$ & $\begin{array}{l}\text { ddY mouse, } \\
n=20\end{array}$ & $\begin{array}{l}\text { REM-SD for } 2 \\
\text { consecutive days }\end{array}$ & $\begin{array}{l}\text { Comparison of two independent } \\
\text { groups: } \\
\text { REM-SD vs untreated controls }\end{array}$ & $\begin{array}{l}\text { Nociceptive thresholds: } \\
\text { - thermal (hot plate test) }\end{array}$ & $\begin{array}{l}\text { No difference in the hot plate test } \\
\text { between the groups }\end{array}$ \\
\hline $\begin{array}{l}\text { Onen et al, } \\
2000(27)\end{array}$ & $\begin{array}{l}\text { Wistar rat, } \\
\mathrm{n}=16\end{array}$ & $\begin{array}{l}\text { REM-SD for } 3 \\
\text { consecutive days }\end{array}$ & $\begin{array}{l}\text { Comparison of two independent } \\
\text { groups (REM-SD vs controls) } \\
\text { including repeated measures with } \\
\text { the conditions: } \\
\text { - baseline } \\
\text { - treatment } \\
\text { - recovery }\end{array}$ & $\begin{array}{l}\text { Nociceptive thresholds: } \\
\text { - mechanical (paw } \\
\text { pressure test) }\end{array}$ & $\begin{array}{l}\text { Decreased nociceptive } \\
\text { thresholds after } 48 \mathrm{~h} \text { and } 72 \mathrm{~h} \\
\text { REM-SD } \\
\text { Recovery sleep after REM-SD } \\
\text { produced increased nociceptive } \\
\text { thresholds }\end{array}$ \\
\hline $\begin{array}{l}\text { Onen et al, } \\
2001 \text { (28) }\end{array}$ & $\begin{array}{l}\text { Wistar rat, } \\
\mathrm{n}=64\end{array}$ & $\begin{array}{l}\text { REM-SD for } 3 \\
\text { consecutive days }\end{array}$ & $\begin{array}{l}\text { Comparison of two independent } \\
\text { groups (REM-SD vs controls) } \\
\text { including repeated measures } \\
\text { with the conditions: } \\
\text { - baseline } \\
\text { - treatment }\end{array}$ & $\begin{array}{l}\text { Nociceptive thresholds: } \\
\text { - thermal (hot water } \\
\text { tail-immersion test) } \\
\text { - mechanical (paw } \\
\text { pressure test) } \\
\text { Quantification of } \\
\text { nociceptive behavior: } \\
\text { - vocalizations to noxious } \\
\text { electrical stimuli } \\
\text { - behavioral response to } \\
\text { noxious chemical stimuli } \\
\text { (formalin test) }\end{array}$ & $\begin{array}{l}\text { REM-SD induced decreased } \\
\text { nociceptive thresholds to thermal } \\
\text { and mechanical stimuli } \\
\text { REM-SD increased number and } \\
\text { intensity of vocal responses to } \\
\text { electrical stimuli } \\
\text { No differences in the formalin } \\
\text { test between or within groups }\end{array}$ \\
\hline $\begin{array}{l}\text { Dametto et al, } \\
2002(29)\end{array}$ & $\begin{array}{l}\text { Wistar rat, } \\
\text { n not } \\
\text { stated }\end{array}$ & $\begin{array}{l}\text { REM-SD for } 4 \\
\text { consecutive days } \\
\text { (in groups of } 6 \\
\text { rats) }\end{array}$ & $\begin{array}{l}3 \times 2 \text { factorial design: } \\
\text { - REM-SD vs two different control } \\
\text { groups with no REM-SD } \\
\text { - Social stable vs social unstable } \\
\text { conditions }\end{array}$ & $\begin{array}{l}\text { Nociceptive thresholds: } \\
\text { - electrical foot shocks with } \\
\text { assessment of flinch } \\
\text { response and/or } \\
\text { vocalization }\end{array}$ & $\begin{array}{l}\text { No difference between the } \\
\text { groups in flinch response } \\
\text { REM-SD deprived animals showed } \\
\text { higher vocalization-thresholds } \\
\text { No interaction of REM-SD with } \\
\text { social stress during SD }\end{array}$ \\
\hline
\end{tabular}


treatment period of $96 \mathrm{~h}$, antinociceptive opioidergic mechanisms were activated either by stress produced by swimming for five minutes in ice cold water or by the intracerebroventricular (icv) application of the enkephalinase-inhibitor phosphoramidon or morphine. All three opioidergic treatments increased the thresholds for paw-pinch in both the control and the "stress" animals. However, in the rats deprived from REM sleep, these effects were not present.

In a subsequent study, Ukponmwan et al (25) considered the dependency of opioidergic antinociception on the availability of monoamines. Consequently, they did not only induce antinociception by application of phosphoramidon (icv) as in the preceding study but also tried in some of the experimental conditions to augment the effect by concurrent application of both the monoamino oxidase (MAO)-B inhibitor deprenyl (intraperitoneally) and the MAO-B substrate betaphenylethylamine (icv). Deprenyl and beta-phenylethylamine potentiated the antinociceptive effects of phosphoramidon. This effect was abolished by an REM sleep deprivation of $96 \mathrm{~h}$. Taken together, the two studies of Ukponmwan et al suggest that REM sleep deprivation interferes with pain inhibitory effects mediated by opioidergic and monoaminergic mechanisms.

Asakura et al (26) investigated the consequences of REM sleep deprivation over $48 \mathrm{~h}$ in mice using a variety of behavioural and neurochemical tests. They found no impact of REM sleep deprivation on nociceptive sensitivity as assessed by the hot-plate test.

Onen et al (27) assessed the vocalization threshold to noxious mechanical stimuli during three days of REM sleep deprivation and a subsequent recovery period of four days. REM sleep deprivation did not augment nociception from the very beginning but only after the second day. During recovery, the thresholds normalized with a delay of $48 \mathrm{~h}$ with a tendency to "overshoot" toward increased nociceptive thresholds. This observation of a normalization contrasts with the findings of Hicks et al $(22,23)$, who continued to observe enhanced nociception even after a period of $48 \mathrm{~h}$ of recovery sleep. In a subsequent study, Onen et al (28) examined the effect of REM sleep deprivation over three days using a variety of tests of nociception (paw pressure test, hot water immersion test, tail electric shock test, formalin test) in Wistar rats. REM sleep deprivation increased the nociceptive sensitivity to mechanical, thermal and electrical stimuli, but not to chemical stimuli (formalin test). In a recent study, Dametto et al (29) investigated the effects of REM sleep deprivation in Wistar rats over $96 \mathrm{~h}$ with a focus on performance in different conditioning tasks. They also assessed the nociceptive thresholds (vocalization or flinch behaviour to electrical foot shocks) as a covariate to examine their influence on learning performance. The authors used a novel sleep deprivation procedure ("modified multiple platform technique"), in which the rats are placed with mates onto platforms. By use of this method, they observed an increased vocalization threshold but no change in flinch behaviour. The indication of an antinociceptive effect of REM sleep deprivation, which contrasts with all other animal studies described so far, might be due to the differences in methods used (eg, social contact was allowed only in the modified multiple platform technique).

\section{SUMMARY OF THE EXPERIMENTAL INVESTIGATIONS OF ANIMALS}

The experimental animal data are much more consistent than those obtained from studies in humans (Table 2). REM sleep deprivation was observed to increase nociceptive behaviour in almost all studies. This suggests a hyperalgesic action of REM sleep deprivation. REM sleep deprivation appeared to prevent the analgesic action of endogenous and exogenous opioids. Furthermore, the potentiation of the analgesic action of opioids by monoamines was abolished by REM sleep deprivation. Although many of the animal studies were controlled and had a sufficient sample size, the exclusive focus on REM sleep deprivation does not resolve issues regarding the effects of depriving NREM sleep stages. Thus, it might be possible that the observed effects are not due to a specific REM sleep deprivation but due to a general and unspecific disruption of sleep.

\section{MECHANISMS OF ACTION}

The majority of the studies on the relationship between sleep deprivation or sleep disruption and pain are able to describe this issue, but their results are not able to allow for conclusions about the mechanisms of action. First hints on the mechanisms of action responsible for the hyperalgesic effect of sleep deprivation were provided by the study of Ukponmwan et al (24). According to their results, the analgesic action of endogenous and exogenous opioids is dependent on undisturbed sleep architecture/continuity because selective REM sleep deprivation prevents opioid analgesia. This points to an effect of REM sleep deprivation or disruption of sleep continuity in general on the activity of the opioid system. Sleep deprivation may cause an inhibition of opioid protein synthesis (30) and/or a reduced affinity of mu- and delta-opioid receptors (31). The potentiation of the opioidergic analgesic effects, produced by the application of enkephalinase-inhibitors and an MAO-B inhibitor or by MAO-B substrates, can be nullified by REM sleep deprivation (25).

This suggests the involvement of further neurotransmitter systems. The MAO-B inhibitor deprenyl stimulates dopaminergic but also serotoninergic activity (32), the latter of which is of special interest in the context of sleep and pain regulation. For example, tryptophan depletion leads to a loss of potency of morphine in producing analgesia (33). This effect is due to the neurochemistry of the descending pain inhibitory control system, which contains opioidergic and monoaminergic (serotoninergic, noradrenergic) links (34). Furthermore, decreased levels of 5-HT and 5-hydroxyindole acetic acid in different brain areas were found in rats after REM sleep deprivation for $96 \mathrm{~h}$ (35,36). One can speculate that REM sleep deprivation, or a disruption of sleep continuity in general, renders the serotonin system functionally unable to support pain inhibition produced by opioidergic activation. These speculations are limited by the fact that only long periods of sleep deprivation or sleep disruption (greater than $72 \mathrm{~h}$ ) were investigated. In contrast, shorter periods of sleep deprivation (less than or equal to $24 \mathrm{~h}$ ) have appeared to enhance 5 -HT activity in animals in various cerebral structures (3). However, a recent study of Bjorvatn et al (37) using in vivo microdialysis showed a gradual decline of extracellular serotonin levels during an $8 \mathrm{~h}$ sleep deprivation period in two different brain structures 
(frontal cortex, hippocampus), which are projection areas of the dorsal and median raphé nuclei.

The time course of the overall change in activity of the 5-HT system induced by sleep deprivation is difficult to determine because presynaptic (release, turnover) or postsynaptic changes (receptor density, receptor sensitivity) may be produced. Moreover, adaptive regulatory processes counterbalancing these changes can be assumed. Consequently, it is difficult to predict the direction of the 5-HT modulated change in the pain system at a given time. Furthermore, there is evidence that other neurotransmitter systems (especially noradrenergic and cholinergic) and neuroimmunological factors (particulary the interleukins [38]) are affected by sleep deprivation and are involved in the modulation of pain.

The idea of a transient disturbance of the descending pain inhibitory control system by sleep deprivation is congruent with the changes in pain experience observed in humans. Sleep deprivation appears to enhance pressure pain sensitivity and to induce muscle pain, as shown in this review. Muscle nociception is much more subject than skin nociception to the descending pain inhibitory system (27).

To further examine these ideas, experiments that are designed to examine specific mediating factors (such as opioidergic and serotoninergic neurotransmission), and are capable of delineating the active part of sleep deprivation and the affected part of the pain system, are necessary. A variety of methodological approaches seems to be useful for that purpose,

\section{REFERENCES}

1. Morin CM, Gibson D, Wade J. Self-reported sleep and mood disturbance in chronic pain patients. Clin J Pain 1998;14:311-4.

2. Foo H, Mason P. Brainstem modulation of pain during sleep and waking. Sleep Med Rev 2003;7:145-54.

3. Asikainen M, Toppila J, Alanko L, Ward DJ, Stenberg D, Porkka-Heiskanen T. Sleep deprivation increases brain serotonin turnover in the rat. Neuroreport 1997;8:1577-82.

4. Gardner JP, Fornal CA, Jacobs BL. Effects of sleep deprivation on serotonergic neuronal activity in the dorsal raphe nucleus of the freely moving cat. Neuropsychopharmacology 1997;17:72-81.

5. Prevot E, Maudhuit C, Le Poul E, Hamon M, Adrien J. Sleep deprivation reduces the citalopram-induced inhibition of serotoninergic neuronal firing in the nucleus raphe dorsalis of the rat. J Sleep Res 1996;5:238-45.

6. Moldofsky H, Scarisbrick P, England R, Smythe H. Musculoskeletal symptoms and non-REM sleep disturbance in patients with "fibrositis syndrome" and healthy subjects. Psychosom Med 1975;37:341-51.

7. Horne JA, Shackell BS. Alpha-like EEG activity in non-REM sleep and the fibromyalgia (fibrositis) syndrome. Electroencephalogr Clin Neurophysiol 1991;79:271-6.

8. Drewes AM, Svendsen L, Taagholt SJ, Bjerregard K, Nielsen KD, Hansen B. Sleep in rheumatoid arthritis: A comparison with healthy subjects and studies of sleep/wake interactions. Br J Rheumatol 1998:37:71-81.

9. Schneider-Helmert D, Whitehouse I, Kumar A, Lijzenga C. Insomnia and alpha-sleep in chronic non-organic pain as compared to primary insomnia. Neuropsychobiology 2001;43:54-8.

10. Agargun MY, Tekeoglu I, Gunes A, Adak B, Kara H, Ercan M. Sleep quality and pain threshold in patients with fibromyalgia. Compr Psychiatry 1999;40:226-8.

11. Jennum P, Drewes AM, Andreasen A, Nielsen KD. Sleep and other symptoms in primary fibromyalgia and in healthy controls. J Rheumatol 1993;20:1756-9.

12. Smith RG. The epidemiology and treatment of depression when it coexists with somatoform disorders, somatization or pain. Gen Hosp Psychiatry 1992;14:265-72.

13. Raymond I, Nielsen TA, Lavigne G, Manzini C, Choiniere M. Quality of sleep and its daily relationship to pain intensity in hospitalized adult burn patients. Pain 2001;92:381-8. such as the use of agonist/antagonist strategies, the assessment of neuroendocrinological and neuroimmunological factors and of neurotransmitters and their metabolites, the comparison of selective and total sleep deprivation, the use of experimental pain measures reflecting various levels of the pain system, and the use of human and animal studies. In addition, the relationship between abnormalities in sleep physiology and pain in clinical conditions with specified evidence of altered neurochemical systems needs further investigation.

\section{CONCLUSIONS}

In this review, evidence that the deprivation or the disturbance of sleep enhances pain sensitivity and causes pain was examined. Pain disturbs sleep by inducing arousal and triggering all other neurobiological sequels of stress that are incompatible with an undisturbed sleep. Hence, an ongoing cycle might arise starting either with disturbed sleep or with pain in which the two components stabilize or even augment each other. Accordingly, sufficient management of disturbed sleep might alleviate pain. On the other hand, better pain relief may promote more restorative sleep, which then further assists in long-term pain relief.

ACKNOWLEDGEMENTS: This project was supported by the German Ministry for Education and Research within the promotional emphasis "German Research Network on Depression".

14. Moldofsky H, Scarisbrick P. Induction of neurasthenic musculoskeletal pain syndrome by selective sleep stage deprivation. Psychosom Med 1976;38:35-44.

15. Drewes AM, Rossel P, Arendt-Nielsen L, et al. Sleepiness does not modulate experimental joint pain in healthy volunteers. Scand J Rheumatol 1997;26:399-400.

16. Older SA, Battafarano DF, Danning CL, et al. The effects of delta wave sleep interruption on pain thresholds and fibromyalgia-like symptoms in healthy subjects; correlations with insulin-like growth factor I. J Rheumatol 1998;25:1180-6.

17. Lentz MJ, Landis CA, Rothermel J, Shaver JL. Effects of selective slow wave sleep disruption on musculoskeletal pain and fatigue in middle aged women. J Rheumatol 1999;26:1586-92.

18. Arima T, Svensson P, Rasmussen C, Nielsen KD, Drewes AM, Arendt-Nielsen L. The relationship between selective sleep deprivation, nocturnal jaw-muscle activity and pain in healthy men. J Oral Rehabil 2001;28:140-8.

19. Onen SH, Alloui A, Gross A, Eschallier A, Dubray C. The effects of total sleep deprivation, selective sleep interruption and sleep recovery on pain tolerance thresholds in healthy subjects. J Sleep Res 2001;10:35-42.

20. Graven-Nielsen T, Mense S. The periphal apparatus of muscle pain: Evidence from animal and human studies. Clin J Pain 2001;17:2-10.

21. Mense S. Neurobiological concepts of fibromyalgia - the possible role of descending spinal tracts. Scand J Rheumatol Suppl 2000;113:24-9.

22. Hicks RA, Moore JD, Findley P, Hirshfield C, Humphrey V. REM sleep deprivation and pain thresholds in rats. Percept Mot Skills 1978:47:848-50.

23. Hicks RA, Coleman DD, Ferrante F, Sahatjian M, Hawkins J. Pain thresholds in rats during recovery from REM sleep deprivation. Percept Mot Skills 1979;48:687-90.

24. Ukponmwan OE, Rupreht J, Dzoljic MR. REM sleep deprivation decreases the antinociceptive property of enkephalinase-inhibition, morphine and cold-water-swim. Gen Pharmacol 1984;15:255-8.

25. Ukponmwan OE, Rupreht J, Dzoljic M. An analgesic effect of enkephalinase inhibition is modulated by monoamine oxidase-B and REM sleep deprivations. Naunyn Schmiedebergs Arch Pharmacol 1986;332:376-9. 
26. Asakura W, Matsumoto K, Ohta H, Watanabe H. REM sleep deprivation decreases apomorphine-induced stimulation of locomotor activity but not stereotyped behavior in mice. Gen Pharmacol 1992;23:337-41.

27. Onen SH, Alloui A, Eschalier A, Dubray C. Vocalization thresholds related to noxious paw pressure are decreased by paradoxical sleep deprivation and increased after sleep recovery in rat. Neurosci Lett 2000;291:25-8.

28. Onen SH, Alloui A, Jourdan D, Eschallier A, Dubray C. Effects of rapid eye movement (REM) sleep deprivation on pain sensitivity in the rat. Brain Res 2001;900:261-7.

29. Dametto M, Suchecki D, Bueno OFA, Moreira KM, Tufik S, Oliveira GM. Social stress does not interact with paradoxical sleep deprivation induced memory impairment. Behav Brain Res 2002;129:171-8.

30. Shapiro C, Girdwood P. Protein synthesis in rat brain during sleep. Neuropharmacology 1981;20:457-60.

31. Fadda P, Tortorella A, Fratta W. Sleep deprivation decreases mu and delta opioid receptor binding in the rat limbic system. Neurosci Lett 1991;129:315-7.

32. Celada P, Artigas F. Monoamine oxidase inhibitors increase preferentially extracellular 5-hydroxytryptamine in the midbrain raphe nuclei. A brain microdialysis study in the awake rat. Naunyn Schmiedebergs Arch Pharmacol 1993;347:583-90.

33. Abbott FV, Etienne P, Franklin KB, Morgan MJ, Sewitch MJ, Young SN. Acute tryptophan depletion blocks morphine analgesia in the cold-pressor test in humans. Psychopharmacology 1992;108:60-6.

34. Basbaum AI, Fields HL. Endogenous pain control systems: Brainstem spinal pathways and endorphin circuitry. Annu Rev Neurosci 1984;7:309-38.

35. Farooqui SM, Brock JW, Zhou J. Changes in monoamines and their metabolite concentrations in REM sleep-deprived rat forebrain nuclei. Pharmacol Biochem Behav 1996;54:385-91.

36. Blanco-Centurion CA, Salin-Pascual RJ. Extracellular serotonin levels in the medullary reticular formation during normal sleep and after REM sleep deprivation. Brain Res 2001;923:128-36.

37. Bjorvatn B, Gronli J, Hamre F, et al. Effects of sleep deprivation on extracellular serotonin in hippocampus and frontal cortex of the rat. Neuroscience 2002;113:323-30.

38. Rogers NL, Szuba MP, Staab JP, Evans DL, Dinges DF.

Neuroimmunologic aspects of sleep and sleep loss. Semin Clin Neuropsychiatry 2001;6:295-307. 


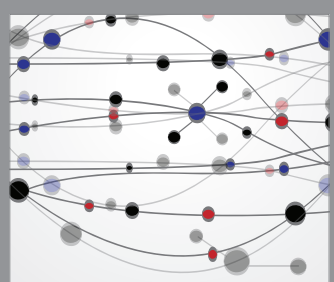

The Scientific World Journal
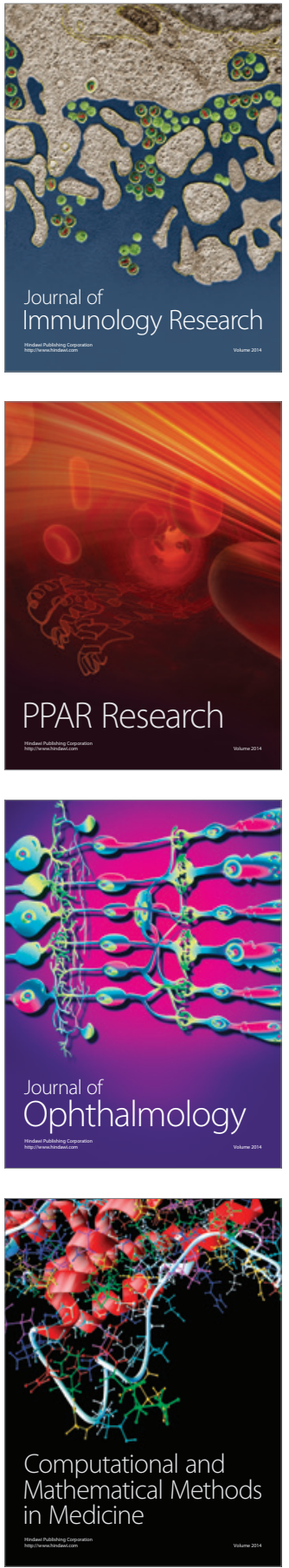

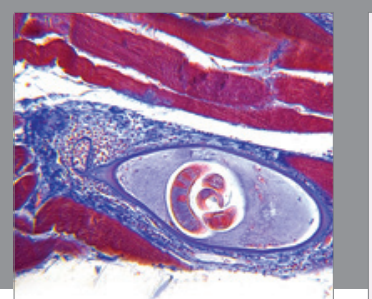

Gastroenterology Research and Practice

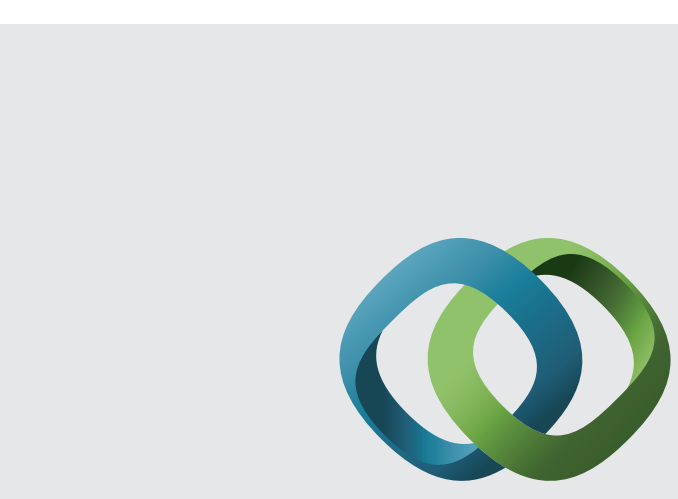

\section{Hindawi}

Submit your manuscripts at

http://www.hindawi.com
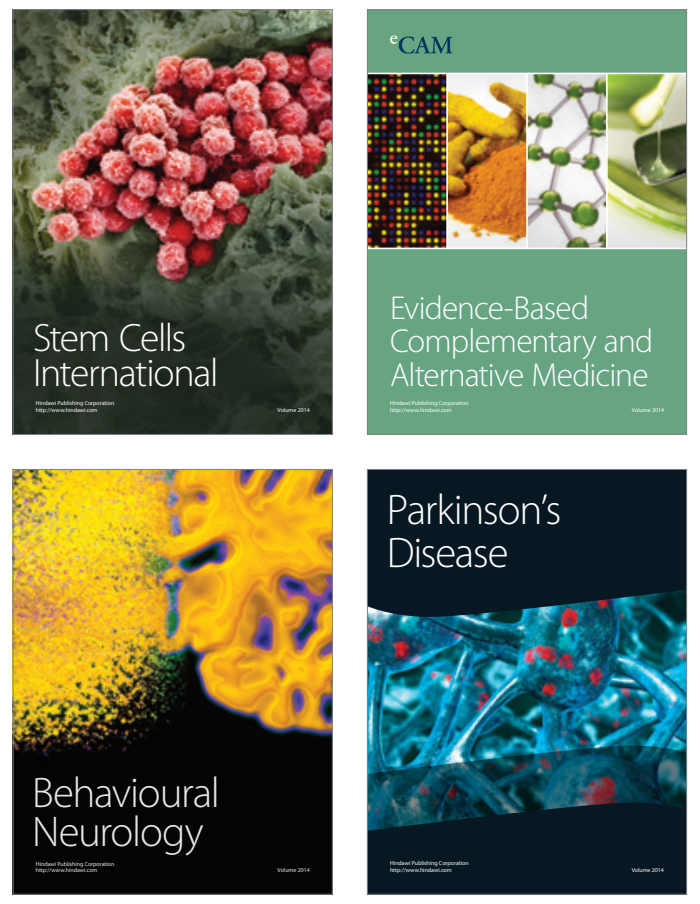
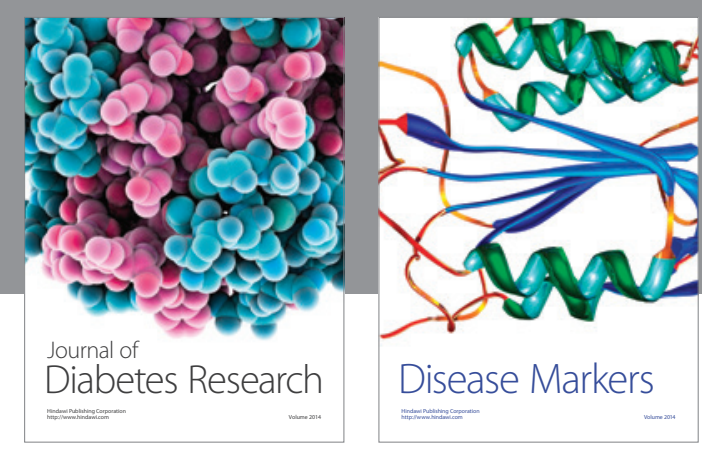

Disease Markers
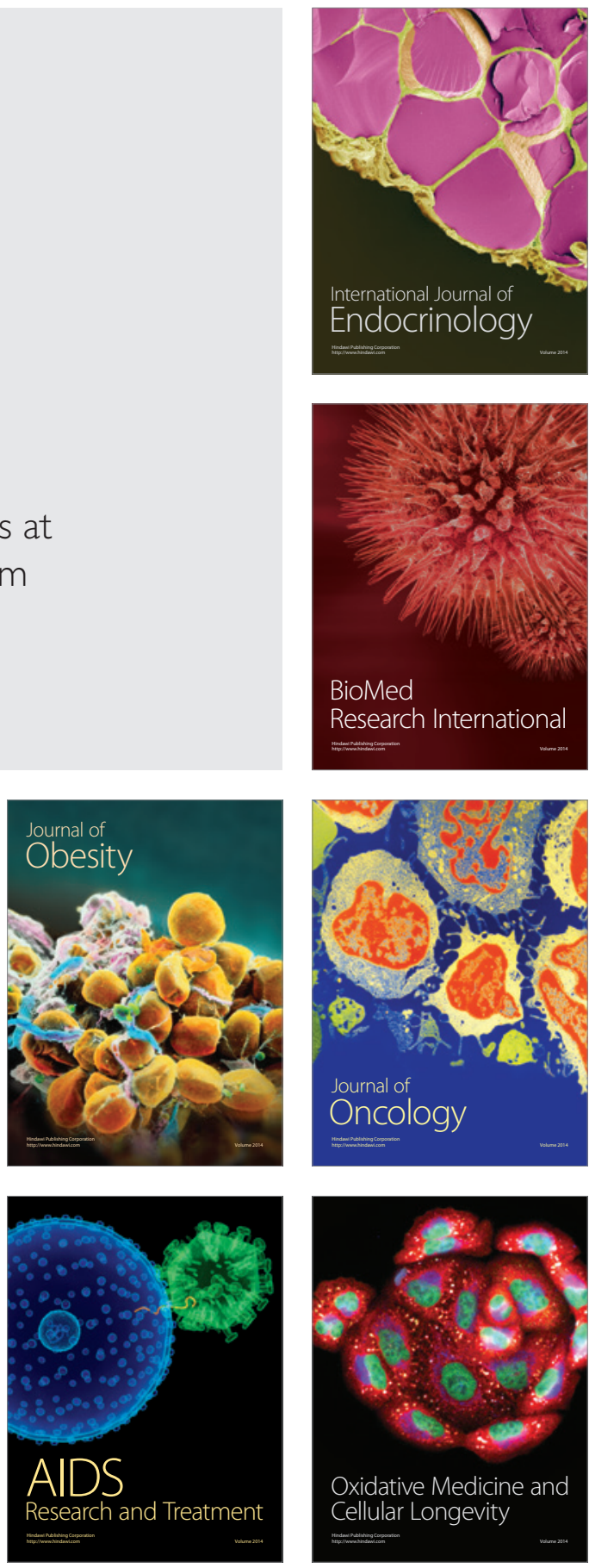